\title{
PENGELOLAAN SISTEM PERIZINAN DALAM RANGKA MEWUJUDKAN IKLIM USAHA BAGI USAHA MIKRO, KECIL DAN MENENGAH DI DAERAH
}

\author{
Teuku Ahmad Yani \\ Email:teuku_yani@yahoo.com
}

\begin{abstract}
The licensee is interesting point for business entity and goverment. The system of district licensee should make good condition for every side. Therefore, the local goverment should do reformation and deregulation about the local of licensee. The license is related with retribution that must be paid by business when need licensee from local goverment. For making the positive thinking the system regarding license, the local goverment should do not always related with retibution.
\end{abstract}

Key Word: Licensee, retribution, local goverment

\begin{abstract}
Abstrak
Pengizinan merupakan titik yang menarik untuk entitas bisnis dan pemerintah. Sistem pengizinan daerah sebaiknya membuat kondisi yang baik untuk setiap sisi. Oleh karena itu, Pemerintah daerah seharusnya melakukan reformasi dan deregulasi tentang pengizinan daerah. Izin berkaitan dengan retribusi yang harus dibayar oleh seorang bisnis ketika membutuhkan pengizinan dari pemerintah daerah. Untuk membuat pemikiran positif tentang sistem perizinan, pemerintah daerah seharusnya tidak selalu berhubungan dengan retribusi.
\end{abstract}

Kata Kunci : Pengizinan, retribusi, pemerintah daerah

\section{A. Pengantar}

Sumber daya alam yang tersedia di Indonesia sangat melimpah ruah, baik itu di atas bumi, dalam perut bumi, maupun di laut. Namun sayangnya sumber daya tersebut belum dapat diberdayakan atau diolah dengan baik oleh warga negara Indonesia untuk kemamkmurannya. 
Kegiatan pengolahan sumber daya alam di Indonesia terbuka selebarlebarnya bagi seluruh komponen masyarakat, baik individu, kelompok masyarakat, dunia usaha baik yang berbentuk badan usaha negara, badan usaha swasta, maupun koperasi.

Undang-Undang Dasar Negara Republik Indonesia, sebagaimana dimaksudkan dalam Pasal 33 dengan tegas menyebutkan bahwa kekayaan alam harus dimanfaatkan sebesar-besarnya bagi kesejahteraan rakyat Indonesia. Demikian pula, kegiatan di luar pengolahan sumber daya alam juga diberikan ruang kepada dunia usaha.

Sebagai negara hukum, pemerintah negara Republik Indonesia dalam memberikan ruang kepada masyarakat dan dunia usaha telah membuat berbagai regulasi di bidang perizinan guna menjamin bahwa keberadaan dunia usaha tidak memberikan dampak negatif bagi kehidupan bangsa Indonesia. Perizinan telah menjadi sistem dalam kehidupan usaha di Indonesia, baik itu izin yang dikeluarkan oleh Pemerintah Pusat, Pemerintah Provinsi maupun Pemerintah Kabupaten/Kota.

Namun acap kali, keberadaan perizinan ini pula telah menjadi momok bagi dunia dalam menjalankan usahanya. Perizinan telah menjadi salah satu penghambat bagi dunia usaha dalam menjalankan usahanya, terutama bagi kelompok usaha Mikro, kecil dan menengah (Undang-Undang Usaha Mikro Nomor 20 Tahun 2008).

Padahal, di Indonesia keberadaan Usaha Micro Kecil dan Menengah (UMKM) telah diakui sebagai kekuatan strategis dan sangat menentukan dalam membentengi krisis ekonomi sebagaimana terjadi pada tahun 1998. Selain itu keberadaan UMKM sangat penting untuk mempercepat pembangunan daerah, oleh karena pertumbuhan Usaha Mikro kecil dan Menengah setiap tahun mengalami peningkatan jumlah UMKM di Indonesia.

Peranan besar UMKM dalam peningkatan pertumbuhan perekonomian Indonesia, disebabkan UMKM banyak menggunakan jumlah penduduk Indonesia sebagai tenaga kerja. UMKM berperan untuk menambah lapangan pekerjaan. Hal ini tentunya berbeda dengan perusahaan besar yang lebih menggunakan teknologi, sehingga penyerapan tenaga kerja terbatas. Walaupun memakai tenaga kerjanyapun, harus memiliki kualifikasi tertentu. 
Permasalahan utama dari UMKM dalam mengembangkan usahanya terbentur perizinan. Sebagian besar UMKM di Indonesia tidak memiliki izin dari Pemerintah Daerah setempat, sehingga mengalami kesulitan dalam mengembangkan usahanya. Pihak perbankan, dalam memberikan pinjaman kepada UMKM selalu mensyaratkan adanya izin, selain persoalan jaminan (anggunan) yang disediakan.

\section{B. Maksud dan Tujuan}

Penulisan ini bertujuan untuk memberikan suatu ilmu pengetahuan untuk memahami aspek teori dan aturan tentang perizinan yang diberlakukan terhadap UMKM. Selain itu, secara praktis adanya tulisan ini diharapkan dapat menjadi rujukan dalam mengatur perizinan di daerah, dalam menumbuhkan iklim usaha sebagai diamanatkan dalam peraturan perundang-undangan.

\section{Metode Penelitian}

Tulisan ini merupakan suatu penelitian normatif, yang dipadukan pula dengan pengamatan secara empiris yang dipraktekkan oleh pemerintah daerah, sehingga dapat menggambarkan sistem perizinan bagi UMKM. Tujuan penulisan ini adalah untuk menjelaskan kaedah-kaedah perizinan bagi UMKM sebagai sistem dalam sistem hukum di Indonesia.

\section{Sistem Perizinan}

Kata sistem dipergunakan untuk menunjukkan banyak hal, tetapi secara garis besar dapat dikelompokkan dalam dua hal yakni pertama, pengertian sistem sebagai entitas, sesuatu wujud benda (abstrak maupun konkret termasuk konseptual) dan kedua, pengertian sistem sebagai suatu metode atau tata cara. Tan Kamello (2014, hal 145 ).

Secara sederhana sistem diartikan sebagai a set af element, such as people, things, and concepts, which are related to achieve a mutual goa, Robert G Murdik dan Joel E. Ross (1982- Hal 4) . Pengertian lain secara etimologi disebutkan system is a group of related parts which work together forming a whole Burut Milla, Harlow (1987-hal 1075). sistem adalah kumpulan dari asas-asas yang memiliki keterpaduan, sehingga menjadi landasan norma, dimana kemudian dibangun tertib hukum, Mariam Darus Badrulsaman (1983 hal 15). 
Dari pengertian tersebut, sistem perizinan dimaksudkan adalah keseluruhan langkah-langkah yang berkaitan dengan perizinan, baik dari segi aturan yang menyangkut substansi perizinan maupun dari segi kelembagaannya.

Oleh karena itu, sistem perizinan seharusnya menjadi alat penyeimbang antara tuntutan dunia usaha dan upaya perlindungan bagi kepentingan masyarakat, misalnya perlindungan dan pengelolaan lingkungan hidup, (Undang-Undang Nomor 32 2009).

Mengenai apa yang dimaksudkan izin selalu menjadi perdebatan. Tanpa mengabaikan perbedaan pendapat tentang izin, di sini perlu dikemukan satu pengertian izin yang sangat relevan dengan naskah akademik ini.

Menurut kamus hukum izin (vergunning) merupakan perkenan/izin dari pemerintah berdasarkan undang-undang atau peraturan pemerintah yang disyaratkan untuk perbuatan yang pada umumnya memerlukan pengawasan khusus, tetapi yang pada umumnya tidaklah dianggap sebagai hal-hal yang ama sekali tidak dikehendaki, S.J Fockema Andreae (dalam Ridwan Hal 207).

Izin bagi UMKM yang diwajibkan di daerah, misalnya adalah perizinan gangguan, perizinan usaha, perizinan mendirikan bangunan, dan perizinan lainnya sebagai instrumen pengedalian kegiatan usaha.

Dengan sistem perizinan, kegiatan usaha bukan lah samasekali tidak dikehendaki, tetapi kegiatan yang memerlukan pengawasan khusus karena sangat berpotensi pula adanya dampak negatif bagi masyarakat sekitar. Oleh kerana itu sudah sepantasnya kegiatan dunia usaha perlu dikendalikan dengan instrumen perizinan.

Sesuai dengan sifatnya, individual dan konkret, ketetapan merupakan ujung tombak dari instrument hukum dalam penyelenggaraan pemerintahan atau sebagai norma penutup dalam rangkaian norma hukum. Izin termasuk sebagai ketetapan yang bersifat konstitutif, yakni ketetapan yang menimbulkan hak baru yang sebelumnya tidak dimiliki oleh seseorang yang namanya tercantum dalam ketetapan itu, atau ketetapan yang memperkenankan sesuatu yang sebelumnya tidak diperbolehkan. Sebagai ketetapan, izin itu dibuat dengan ketentuan dan persyaratan yang berlaku pada ketetapan pada umumnya. 
Sebagai tindakan hukum, maka pemberian izin harus ada wewenang yang diberikan oleh peraturan perundang-undangan atau harus berdasarkan pada asas legalitas. Tanpa ada wewenang, tindakan itu menjadi tidak sah. Untuk itu, menurut Soehino, syarat-syarat dalam izin itu bersifat konstitutif dan kondisional. Bersifat konstitutif, oleh karena ditentukan suatu perbuatan atau tingkah laku tertentu yang harus (terlebih dahulu) dipenuhi, artinya dalam pemberian izin itu ditentukan suatu perbuatan konkret, dan bila tidak dipenuhi dapat dikenakan sanksi. Bersifat kondisional, oleh karena penilaian tersebut baru ada dan dapat dilihat serta dapat dinilai setelah perbuatan atau tingkah laku yang disyaratkan itu terjadi, Soehino (1984 hal 97).

Lembaga yang melaksanakan pelayanan publik dituntut untuk mampu memberikan pelayanan yang berkualitas dengan cepat, tepat dan mudah, dan prosedur yang sederhana.

Pelayanan yang baik hanya akan diwujudkan apabila di dalam organisasi pelayanan terdapat sistem pelayanan yang mengutamakan kepentingan masyarakat khususnya pengguna jasa pelayanan dan sumber daya manusia yang berorientasi pada kepentingan pelanggan dan masyarakat sebagai stakeholders. Fokus kepentingan masyarakat merupakan hal yang mutlak dilakukan tiap-tiap unit pelayanan, karena keberadaan unit pelayanan publik bergantung pada ada tidaknya masyarakat membutuhkan jasa pelayanan publik.

\section{E. Keterkaitan antara Iklim Usaha Dengan Perizinan}

Iklim usaha yang sehat dapat diartikan sebagai faktor-faktor yang bersifat khusus dan berdimensi lokal yang menciptakan insentif dan kesempatan bagi para pelaku usaha skala kecil, menengah, dan besar untuk berinvestasi secara produktif, menciptakan lapangan pekerjaan, dan mengembangkan jenis dan kegiatan usahanya. Terwujudnya iklim usaha yang sehat sangat tergantung pada perilaku dan kebijakan yang disusun oleh pemerintah setempat, Deswanto Marbun dkk (2015 hal 7).

Iklim usaha yang kondusif, mampu memberikan kesempatan kepada seluruh pelaku usaha untuk berkembang secara wajar. Dalam iklim usaha yang kondusif, keberhasilan usaha semata-mata dipengaruhi oleh kemampuan pengusaha 
untuk bersaing dengan pengusaha lain dalam memanfaatkan peluang, Edi Priyono (2013).

Sementara itu, Pasal 1 angka 9 Undang-Undang Nomor 20 Tahun 2008 memberikan pengertian pengertian iklim usaha adalah kondisi yang diupayakan Pemerintah dan Pemerintah Daerah untuk memberdayakan Usaha Mikro, Kecil, dan Menengah secara sinergis melalui penetapan berbagai peraturan perundangundangan dan kebijakan di berbagai aspek kehidupan ekonomi agar Usaha Mikro, Kecil, dan Menengah memperoleh pemihakan, kepastian, kesempatan, perlindungan, dan dukungan berusaha yang seluas-luasnya.

Untuk mewujudkan iklim usaha itu, menurut Pasal 7 Undang-Undang ini tidak hanya menjadi tanggung jawab pemerintah pusat, melainkan juga pemerintah daerah. Dalam Pasal ini, jelas disebutkan bahwa Pemerintah dan Pemerintah Daerah menumbuhkan Iklim Usaha dengan menetapkan peraturan perundangundangan dan kebijakan yang meliputi aspek:
a. pendanaan;
b. sarana dan prasarana;
c. informasi usaha;
d. kemitraan;
e. perizinan usaha;
f. kesempatan berusaha;
g. promosi dagang; dan
h. dukungan kelembagaan.

Dari pasal tersebut, jelaslah bahwa perizinan merupakan indikator penentu terwujudnya iklim usaha. Perizinan ini terkait erat dengan lembaga pemberian izinnya, sehingga banyak daerah telah melakukan terobosan-terobosan dalam memotong birokrasi dalam proses pemberian izin.

Banyak daerah telah membentuk Kantor Pelayanan Terpadu Satu Pintu (KPTSP), misalnya Kabupaten Sragen Provinsi Jawa Tengah semenjak tahun 2001 telah menerapkan sistem keterpaduan dalam pemberian izin dalam suatu institusi daerah. Pengalaman sukses dari Kabupaten Sragen ini telah diikuti oleh banyak daerah, yang kemudian oleh Kementerian Dalam Negeri mengeluarkan Peraturan Menteri Dalam Negeri pada tahun 2006. 
Kemudian, kebijakan pelayanan perizinan terpadu satu pintu ini diberikan dasar hukum yang lebih kuat lagi sebagai perangkat daerah, sebagaimana diatur dalam Peraturan Pemerintah Nomor 41 Tahun 207 Tentang Perangkat Daerah. Berdasarkan dasar hukum ini, maka semua daerah telah membentuk KPTSP ini.

Keberadaan perangkat daerah ini, tentunya harus dibarengi dengan itikad baik untuk melayani dari sumber daya manusia yang ditugaskan untuk melayaninya. Pegawai yang diberi tugas harus merubah maindset dari dilayani menjadi melayani. Oleh sebab itu, pelayanan tidak seharusnya dikaitkan dengan pendapatan yang diperolehnya dari orang yang dilayaninya. Untuk itu, pemerintah daerah telah menyediakan insentif khusus kepada pegawai yang ditempatkan pada perangkat daerah dimaksud.

Selain itu, pegawai yang ditempatkan haruslah pegawai-pegawai yang memiliki kepribadian untuk memiliki sifat melayani. Pelatihan-pelatihan kepribadian kepada pegawai perlu diberikan secara berkelanjutan. Namun sayangnya, dewasa ini penempatan pegawai di perangkat daerah kurang terseleksi dengan baik, baik yang menduduki jabatan sebagai pimpinannya maupun sebagai stafnya. Oleh karenanya, maindset pelayanan dari perangkat daerah mulai dipertanyakan kembali oleh penerima layanan, dalam hal ini dunia usaha.

Oleh karena itu, cita hukum sebagaimana dimaksud dalam Undang-Undang Nomor 25 Tahun 2009 Tentang Pelayanan Publik menjadi tidak tercapai. Menurut Pasal 8 ayat (1) Organisasi Penyelenggara berkewajiban menyelenggarakan pelayanan publik sesuai dengan tujuan pembentukan.

Untuk menjamin pelayanan perizinan yang mampu mewujudkan iklim usaha ini, maka pelayanan publik harus memberikan kepastian tentang waktu pelayanan. Hal ini terkait erat dengan ketentuan yang terdapat dalam Pasal 3 Undang-Undang Nomor 5 Tahun 1986 Tentang Peradilan Tata Usaha Negara. Menurut undang-undang ini, bahwa apabila Badan atau Pejabat Tata Usaha Negara tidak mengeluarkan keputusan, sedangkan hal itu menjadi kewajibannya, maka hal tersebut disamakan dengan Keputusan Tata Usaha Negara. Berikutnya ditegaskan pula, bahwa jika suatu Badan atau Pejabat Tata Usaha Negara tidak mengeluarkan keputusan yang dimohon, sedangkan jangka waktu sebagaimana ditentukan data peraturan perundang-undangan dimaksud telah lewat, maka Badan atau Pejabat 
Tata Usaha Negara tersebut dianggap telah menolak mengeluarkan keputusan yang dimaksud.

Sementara itu pada bagian yang lain, pada pasal ini ditegaskan pula, bahwa dalam hal peraturan perundang-undangan yang bersangkutan tidak menentukan jangka waktu, maka setelah lewat jangka waktu empat bulan sejak diterimnya permohonan, Badan atau Pejabat Tata Usaha Negara yang bersangkutan dianggap telah mengeluarkan keputusan penolakan.

Ketentuan tersebut memiliki hubungan yang erat dengan ketentuan yang terdapat dalam Pasal 51 Undang-Undang Nomor 25 Tahun 2009 Tentang Pelayanan Publik yang menegaskan bahwa masyarakat dapat menggugat penyelenggara atau pelaksana pelayanan publik melalui peradilan tata usaha negara apabila pelayanan yang diberikan menimbulkan kerugian di bidang tata usaha negara.

\section{F. Hubungan Perizinan dengan Pajak dan Retribusi}

Perizinan terkait erat dengan retribusi yang dapat dikutip oleh daerah. Retribusi telah menjadi sumber pendapatan yang sah bagi daerah dalam meningkatkan pendapatan asli daerah (PAD) sebagaimana dimaksudkan dalam Undang-Undang Nomor 28 Tahun 2009 Tentang Pajak dan Retribusi Daerah.

Menurut Halim (2004) ciri utama suatu daerah mampu melaksanakan otonomi sebagai berikut:

1. kemampuan keuangan daerah, yang berarti daerah tersebut memiliki kemampuan dan kewenangan untuk menggali sumber-sumber keuangan, mengelola dan menggunakan keuangannya sendiri untuk membiayai penyelenggaraan pemerintahan.

2. ketergantungan kepada bantuan pusat harus seminimal mungkin oleh karena itu, Pendapatan Asli Daerah (PAD) harus menjadi sumber keuangan terbesar yang didukung oleh kebijakan perimbangan keuangan pusat dan daerah.

Secara umum, semakin tinggi kontribusi pendapatan asli daerah dan semakin tinggi kemampuan daerah untuk membiayai kemampuannya sendiri akan menunjukkan kinerja keuangan daerah yang positif. Dalam hal ini, kinerja keuangan positif dapat diartikan sebagai kemansirian keuangan daerah dalam 
membiayai kebutuhan daerah dan mendukung pelaksanaan otonomi daerah pada daerah tersebut Andrian Sutedi (2009 hal 11).

Lantas tidak dapat diartikan bahwa pembentukan aturan tentang perizinan di daerah harus selalu dikaitkan dengan retribusi. Undang-Undang Nomor 28 Tahun 2009 telah membatasi jenis-jenis izin yang dapat dikutip retribusi. Karena pada prinsipnya, pengaturan mengenai izin bukan memiliki orientasi utama untuk pengutipan retribusi, melainkan lebih kepada adanya ketertiban dari penerima izin dalam menjalankan usahanya.

Selayaknyalah daerah dalam mengatur masalah perizinan tidak menyebabkan ekonomi biaya tinggi yang sering dikeluhkan oleh UMKM dalam mengurus prizinan di KPTSP. Sudah semestinya, pelayanan perizinan bagi UMKM harus digratiskan, apabila dilihat fungsinya utama sebagai upaya menciptakan ketertiban, sementara keberadaan UMKM telah banyak membantu pemerintah daerah dalam menciptakan lapangan kerja dan mendorong pertumbuhan ekonomi daerah dan nasional.

\section{G. Kesimpulan}

Perizinan merupakan bagian penting bagi dunia usaha dalam menjalankan usaha.Tanpa adanya perizinan maka dunia usaha belum diperbolehkan untuk memulai kegiatan usaha. Sistem perizinan telah menjadi indikator keberhasilan dalam pelayanan publik. Oleh karena itu perizinan telah pula menjadi idikator penentu dalam mewujudkan iklim usaha, sehingga terus didorong untuk melakukan reformasi dan deregulasi di bidang perizinan. Perizinan tidak selayaknya dikaitkan dengan retribusi, sehingga retribusi sudah seharusnya dilepas dari sistem perizinan. 


\section{Daftar Kepustakaan}

Adrian Sutedi, Implikasi Hukum Atas Sumber Pembiayaan Daerah Dalam Kerangka Otonomi Daerah, Sinar Grafika, Jakarta, 2009.

Chandra, Purdi E. “Trik Bisnis Menuju Sukses.” Yogyakarta, CV. Grafika Indah, 2004.

Deswanto Marbun dan kawan-kawan, Iklim Usaha di Timor Tengah Utara, Kajian Perekonomian dan Regulasi Usaha, Semeru Research Istitute, Jakarta, 2015.

Edy Priyono, AKADEMIKA-Center for Public Policy Analysis, Seminar ADBLitbang Deperindag-Pemkab Bekasi, 16 Juni 2003.

Halim, Local Original Revenue as A Source of Development Financing, Makalah disampaikan pada konferensi IRSA ke 6, Yogyakarta, 2004.

Ilmar, Aminuddin, Hukum Penanaman Modal di Indonesia, Kuwais, Jakarta, 2010.

Longman Dictionary of Contemporary English, England: Longman House, Burut Milla, Harlow, 1987.

Mariam Darus Badrulzaman, Mencari Sistem Hukum Benda Nasional, Alumni, Bandung, 1983.

Robert G. Murdick dan Joel E. Ross, Information System for Modern Management, Prentice-Hall of India, New Delhi, 1982.

Soehino, Asas-asas Hukum Tata Pemerintahan, Liberty, Yogyakarta, 1984.

Tan Kamello, Hukum Jaminan Fidusia, Alumni, Bandung, 2014.

Undang-Undang Republik Indonesia Nomor 40 Tahun 2007 Tentang Perseroan Terbatas.

Undang-Undang Republik Indonesia Nomor 2 Tahun 2008 Tentang Usaha Kecil, Mikro dan Menengah.

Undang-Undang Republik Indonesia Nomor 5 Tahun 1999 tentang Larangan Praktek Monopoli dan Persaingan Usaha Tidak Sehat.

Usman, Sunyoto. “Pembangunan dan Pemberdayaan Masyarakat.” Yogyakarta, Pustaka Pelajar, 2004. 